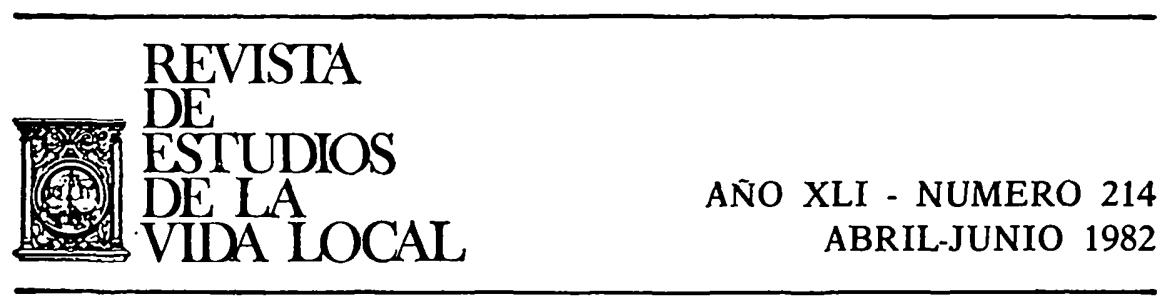

\title{
sumario
}

Págs.

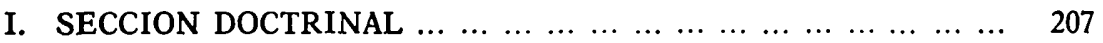

Aurelio Guaita: El territorio valenciano: Sus límites y divisio-

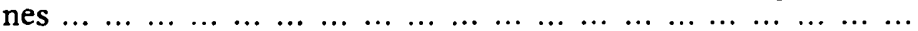

ANDRÉS MOREY: El control de legalidad y la suspensión de acuerdos de los Entes territoriales por el Estado ... ... ..........

José-Ramón Rodríguez-Sabugo Fernández: Ordenanzas y Reglamentos, y límites de los mismos, en la Administración local.

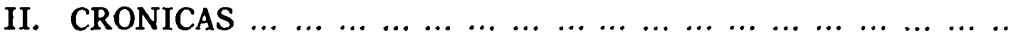

Bartomeu Colom Pastor: La preautonomía de las islas Baleares y el futuro de los órganos provinciales locales en las Co-

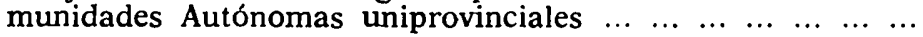

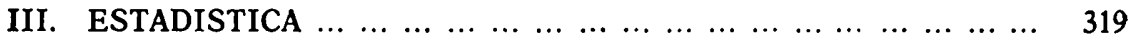

IgNacio Ballester Ros: Distribución geográfica y tipología de los edificios en España

IV. JURISPRUDENCIA $\ldots \begin{array}{llllllllllllllll} & \ldots & \ldots & \ldots & \ldots & \ldots & \ldots & \ldots & \ldots & \ldots & \ldots & \ldots & \ldots & \ldots & \ldots & 345\end{array}$

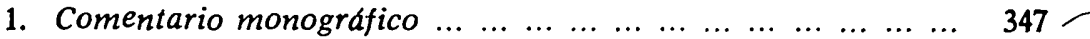

Nemesio RodrfGuez Moro: Los bienes comunales tienen como titular al respectivo Municipio, sin que pueda atribuirse tal titularidad a una Junta vecinal administrativa de las mismas

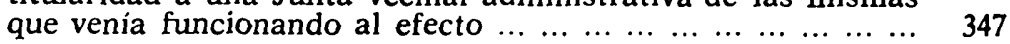

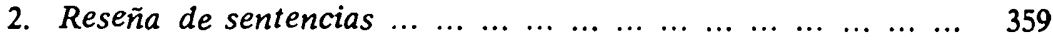

V. $\begin{array}{llllllllllllllllll} & \text { BIBLIOGRAFIA } & \ldots & \ldots & \ldots & \ldots & \ldots & \ldots & \ldots & \ldots & \ldots & \ldots & \ldots & \ldots & \ldots & \ldots & \ldots & \ldots\end{array}$

VI. $\quad$ REVISTA DE REVISTAS $\ldots \begin{array}{lllllllllllllll} & \ldots & \ldots & \ldots & \ldots & \ldots & \ldots & \ldots & \ldots & \ldots & \ldots & \ldots & \ldots & \ldots & 391\end{array}$ 


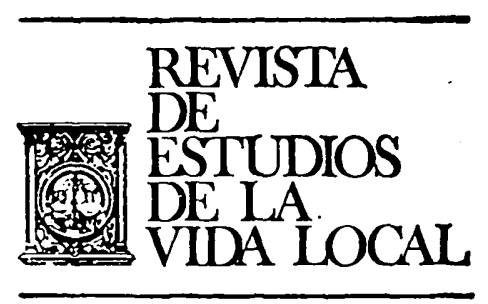

\section{SECCION DOCTRINAL}


REVL-1982, núm. 214. SUMARIO 